Article

\title{
How do Environmental, Social and Governance Initiatives Affect Innovative Performance for Corporate Sustainability?
}

\author{
Qi Zhang ${ }^{1,2, *}$, Lawrence Loh $^{2, *}$ and Weiwei $\mathrm{Wu}^{1}$ \\ 1 School of Management, Harbin Institute of Technology, Harbin 150001, China; wuweiwei@hit.edu.cn \\ 2 Centre for Governance, Institutions and Organisations, NUS Business School, \\ National University of Singapore, Singapore 117592, Singapore \\ * Correspondence: qizhang0320@hit.edu.cn (Q.Z.); bizlohyk@nus.edu.sg (L.L.); Tel.: +86-188-460-12628 (Q.Z.)
}

Received: 2 April 2020; Accepted: 16 April 2020; Published: 21 April 2020

\begin{abstract}
Corporate sustainability has been a long-established topic in the corporate operating process. Much research focuses on the internal relationships among environmental, social and economic dimensions of corporate sustainability, yet few studies have examined the topic from the perspective of environmental, social and governance (ESG) initiatives and innovative performance. Using insights from stakeholder theory, this study develops theoretical linkages between corporate ESG initiatives and innovative performance. It further considers whether these relationships still exist under different institutional development settings. Based on the samples of 433 observations which are listed on the Shanghai and Shenzhen stock exchanges, in China, from 2007 to 2017, empirical results using the method of hierarchical regression analysis have confirmed that corporate environmental initiatives, social initiatives and governance initiatives have direct positive impacts on innovative performance. Furthermore, in examining the interactive effect of individual dimensions of ESG initiatives, the results reveal that corporate governance initiatives play a moderating role in the relationship between environmental initiatives and innovative performance and in the relationship between social initiatives and innovative performance. Finally, the empirical analyses also show that institutional development influences the effectiveness of corporate governance initiatives. This research contributes to extending the prior literature and providing several recommendations for firms to achieve corporate sustainability.
\end{abstract}

Keywords: corporate ESG initiatives; innovative performance; institutional development; corporate sustainability

\section{Introduction}

With the escalation of environmental pollution and social concerns, sustainable corporate development has received increasing attention in recent years [1]. Under the pressure of international schemes (e.g., the Global Reporting Initiative Reporting Framework; the ISO 26000 Guidance on Social Responsibility Guidelines; the United Nations' Global Compact), more and more business entities worldwide have begun to voluntarily integrate corporate sustainability into their operational and managerial strategy through the adoption of related practices [2]. The aim of achieving corporate sustainability is to safeguard the well-being of the human population, protect the natural environment and promote the sustainable development of the economy [1,3]. Therefore, firms aiming to obtain sustainable advantages must focus not only on the generation of superior profits, but also on gathering momentum in environmental, social and governance (ESG) initiatives [4].

Achieving a win-win paradigm in corporate sustainability is a critical focal topic that scholars urgently need to investigate [5]. An outstanding number of studies on corporate ESG initiatives 
have focused on their measurement and their link to economic performance [6-10]. Some studies confirmed their positive relationship from the perspective of financial performance and marketing performance [9-12] and identified the mechanisms linking them to issues such as stakeholder identification [13,14], corporate reputation [15,16], corporate image [17], customer satisfaction [18] and employee engagement $[19,20]$. Other studies regarded corporate ESG initiatives as a cost, which limits the firms' strategic alternatives and reduces their short-term benefits [21,22]. The distinct research perspectives and empirical inconclusiveness have led to the ongoing debate. However, there is little research on understanding the relationships between corporate ESG initiatives and innovative performance, which leads to the competitive advantages that ensure a firm's success. There is especially little research on the interactive effects of different dimensions of corporate ESG initiatives on innovative performance. To fill this gap, this study seeks to investigate the individual effects of corporate environmental initiatives, social initiatives and governance initiatives on innovative performance and how their interactions relate to innovative performance.

Furthermore, it is imperative to realize that the previous research has rarely focused on transition economies specifically characterized by inefficient markets and institutions embedded in specific regions [23]. Firms in the different regions are heavily influenced by different market development and institutional contexts, which results in different degrees of protection of the rights of shareholders and other stakeholders $[23,24]$. Thus, it can be inferred that the impacts of corporate ESG initiatives may vary across different levels of the institutional environment in which a firm operates. Yet the existing studies have not paid full attention to the effects of corporate ESG initiatives under different levels of institutional development. Therefore, it is necessary to explore the relationships between corporate ESG initiatives and innovative performance considering the contingency factors of institutional development in great depth.

To solve the above-mentioned research problem, we propose a moderating model to disentangle the relationships between environmental, social and governance initiatives and innovative performance for corporate sustainability based on the stakeholder theory. The study will extend the existing work in several aspects. First, this study fills an important gap in the field of corporate sustainability by investigating the relationships among corporate, environmental and social governance and economic aspects. Second, this study contributes to corporate ESG literature by further analyzing the interactive effects of environmental, social and governance initiatives on innovative performance. Third, this study adds additional insights to the effectiveness of corporate governance by exploring the fit between corporate governance and institutional development. In addition, it also extends the research on the factors that influence firm innovation.

The following section describes the previous literature. Section 3 constructs a theoretical framework and presents hypotheses. The sample selection, variables and estimation model are provided in Section 4 . Section 5 provides the results and Section 6 summarizes the discussions and conclusions.

\section{Literature Review}

\subsection{Corporate Sustainability}

Corporate sustainability, as a particular topic of business strategy, is receiving growing attention by academics and practitioners [2]. It derives from the concept of sustainable development and extends it to the corporate level, reflecting the attempt to organize and satisfy the needs of the contemporary era without compromising the resources and interests of future generations [1-3]. Many researchers have focused extensively on the stream of corporate sustainability in the past several decades. Initially, the concept of corporate sustainability became the focus of much research. The word "sustainability" first appeared in 1972 in a British article entitled "Blueprint for Survival", which refers exclusively to the ecological aspects of sustainability [25]. Porter associated corporate sustainability with economic growth and stated that sustainable development is an effective means to maximize shareholder value [26]. Over time, the definition of sustainability transcended individual 
aspects. The World Commission on Environment and Development (WCED) first conceptualized it as the requirement to create economic value, protecting ecological environment and providing social welfare to the present and subsequent generations simultaneously [27]. Based on this definition, many scholars referred to corporate sustainability as a multidimensional construct including environmental, economic and social aspects in great depth [22-24,28,29]. For example, Elkington pointed out that corporate sustainability is regarded as the key and ultimate goal of firms aiming at balancing the "Triple Bottom Line" [28]. Furthermore, he also posited that the three aspects of sustainability are inextricably connected and internally interdependent [29]. In addition, a great number of studies regarding the measurement of corporate sustainability and the ways of realizing the goal of sustainability have been developed. Lozano emphasized that firms ought to rethink their roles within society and their impacts on environment, as well as seek to establish stable relationships with stakeholders. They must also implement sustainable development strategies to integrate corporate governance concerns into corporate sustainable operations and achieve superior profits [30]. In recent years, more and more researchers have taken the whole set of sustainable issues related to economic integrity, social equity, environmental integrity and corporate governance into consideration. The outlines of the definition of corporate sustainability are mentioned in Table 1.

Table 1. Outlines on the definition of corporate sustainability.

\begin{tabular}{|c|c|c|c|c|c|}
\hline \multirow{2}{*}{ Study } & \multirow{2}{*}{ Operational Definition } & \multicolumn{4}{|c|}{ Aspects } \\
\hline & & Env- & Soc- & Eco- & Gov- \\
\hline Porter (1985) [26] & $\begin{array}{l}\text { The way of providing the information of corporate operations } \\
\text { in order to improve long-term profitability. }\end{array}$ & & & $\sqrt{ }$ & \\
\hline Lélé (1991) [31] & $\begin{array}{l}\text { The necessary ecological conditions to support the way of life } \\
\text { of future generations. }\end{array}$ & $\sqrt{ }$ & & & \\
\hline $\begin{array}{l}\text { Shrivastava (1995a) } \\
\text { [32] }\end{array}$ & $\begin{array}{l}\text { A way of developing the economy that reconceptualizes the } \\
\text { relation between society and nature. }\end{array}$ & $\sqrt{ }$ & & $\sqrt{ }$ & \\
\hline $\begin{array}{l}\text { Hueting and } \\
\text { Reiinders (1998) }\end{array}$ & $\begin{array}{l}\text { The objective conditions to realize intergenerational equity } \\
\text { and sustainable environment. }\end{array}$ & $\sqrt{ }$ & $\sqrt{ }$ & & \\
\hline Banerjee (2003) [34] & $\begin{array}{l}\text { An attempt to reconcile the conflicts between economic } \\
\text { growth and environmental destruction. }\end{array}$ & $\sqrt{ }$ & & $\sqrt{ }$ & \\
\hline Bansal (2005) [35] & $\begin{array}{l}\text { The principles that firms apply to products, policies and } \\
\text { practices including economic integrity, social equity and } \\
\text { environmental integrity. }\end{array}$ & $\sqrt{ }$ & $\sqrt{ }$ & $\sqrt{ }$ & \\
\hline $\begin{array}{l}\text { Chow and Chen } \\
\text { (2012) [36] }\end{array}$ & $\begin{array}{l}\text { The extent to which firms address their efforts on social, } \\
\text { economic and environmental development. }\end{array}$ & $\sqrt{ }$ & $\sqrt{ }$ & $\sqrt{ }$ & \\
\hline $\begin{array}{c}\text { Ameer and } \\
\text { Othman (2012) [37] }\end{array}$ & $\begin{array}{l}\text { A manifestation of the integration of environmental and social } \\
\text { management in an operational strategy. }\end{array}$ & $\sqrt{ }$ & $\sqrt{ }$ & $\sqrt{ }$ & \\
\hline $\begin{array}{c}\text { Amini and } \\
\text { Bienstock (2014) } \\
\text { [38] }\end{array}$ & $\begin{array}{l}\text { A process of integration pertaining to application and } \\
\text { communication for sustainability including } \\
\text { sustainability-oriented innovation, economy, ecology, } \\
\text { environment. }\end{array}$ & $\sqrt{ }$ & $\sqrt{ }$ & $\sqrt{ }$ & $\sqrt{ }$ \\
\hline $\begin{array}{l}\text { Engert et al. (2016) } \\
\text { [39] }\end{array}$ & $\begin{array}{c}\text { A systematic business approach that considers the long-term } \\
\text { social and environmental impacts on the interests of } \\
\text { stakeholders. }\end{array}$ & $\sqrt{ }$ & $\sqrt{ }$ & $\sqrt{ }$ & $\sqrt{ }$ \\
\hline $\begin{array}{l}\text { Hahn et al. (2018) } \\
\text { [2] }\end{array}$ & $\begin{array}{c}\text { The aim of simultaneously accommodating competing yet } \\
\text { interrelated socially and environmentally responsible values } \\
\text { and economy concerns through management from a paradox } \\
\text { perspective. }\end{array}$ & $\sqrt{ }$ & $\sqrt{ }$ & $\sqrt{ }$ & $\sqrt{ }$ \\
\hline $\begin{array}{l}\text { Montiel et al. } \\
\text { (2019) [40] }\end{array}$ & $\begin{array}{l}\text { The principles with six threshold concept themes, such as } \\
\text { emotional agency, stakeholder dynamics, evolving value } \\
\text { creation, altruism pitfalls, managerial reinvention and } \\
\text { ecological connection. }\end{array}$ & $\sqrt{ }$ & $\sqrt{ }$ & $\sqrt{ }$ & $\sqrt{ }$ \\
\hline
\end{tabular}

\subsection{Corporate Environmental, Social, and Governance Initiatives}

Corporate ESG initiatives refer to the principles, plans or strategies that reflect the philosophy of corporate sustainability [6,7]. With the increase in the proposals to enhance ESG reports from international organizations (i.e., the United Nations' Principles of Responsible Investment (UNPRI), 
Social Accountability 8000 and Global Report Initiative 2013), more firms are integrating ESG issues into managerial strategies and voluntarily disclosing ESG information [8]. In line with these actual conditions, a broad range of recent research began to pay attention to the effects of ESG initiatives on corporate performance [6-9]. With regard to this relationship, two controversial viewpoints prevail in these studies. A proportion of studies reported that corporate ESG initiatives have a positive link to financial performance. For instance, Xie, Nozawa, Yagi et al. considered that a moderate level of ESG disclosure has had a positive influence on corporate efficiency and ESG activities have a non-negative relationship with corporate economic outcomes, measured with corporate efficiency, return on assets and market value [41]. Taliento, Favino and Netti offered an investigation of the link between ESG initiatives and economic performance and confirmed their positive correlation [42]. On the other hand, some studies highlighted the presence of a negative effect in the aforementioned relationship. A study by Halbritter and Dorfleitner argued that no significant abnormal return difference existed in different levels of ESG ratings from the perspective of the portfolios [43]. These diverging viewpoints led to more detailed analyses of the subdimensions of ESG initiatives and their effects on corporate performance [41]. Despite the recognition of the negative individualized effects of each ESG subfactor on financial performance, Duque-Grisales and Aguilera-Caracuel, focusing specifically on multinationals [8], found that little effort and attention have been devoted to the interactive linkages among individual environmental initiatives, social initiatives and governance initiatives, which may be beneficial for figuring out the value-making process of ESG initiatives.

\subsection{Innovative Performance}

Innovation is viewed as a strategic tool for firms to create value and improve sustainable competitive advantages in a dynamic and changing environment [44]. A substantial proportion of studies have investigated the determinant of innovative performance from the perspective of the external organizational environment (i.e., government policy [45] or market competition [46]), structured mechanisms (i.e., social networks [47], innovative alliances [48] or knowledge networks [49]), organizational attributes (i.e., knowledge base [50], absorptive capacity [51], organization learning [52], organizational culture [53]) and individual elements (i.e., human capital [54] and management characteristics [54]). Recently, the academic community has showed an increasingly strong effect of the organizational level on innovative outcomes. More specifically, it emphasized the critical role that the organizational behaviors involved in creating heterogeneous resources or knowledge plays in improving corporate innovative performance based on the resource-based view or the knowledge-based view. Markovic and Bagherzadeh found that the pursuit of external stakeholder co-creation stimulates knowledge sharing, which generates the advantages of innovativeness [55]. Flammer and Kacperczyk also pointed out that corporate social responsibility serves as a defense against knowledge spillovers, increasing long-term productivity [56]. However, the previous research has not fully accounted for the effects of environmental, social and governance initiatives on innovative performance. In particular, it ignores their interactive effects on innovative performance in the integrated ESG framework.

\section{Theoretical Framework and Hypotheses}

\subsection{Theoretical Framework}

Stakeholder theory emphasizes the role of stakeholders in the value creation process [13]. Effectively managing relationships with these stakeholders can be a source for firms to sustain corporate success [10]. Corporate ESG initiatives, defined as the actions that appear to advance the promotion of environment protection, social welfare and corporate governance beyond the requirements of law are the outcome of mitigating stakeholder pressure and maintaining long-term relationships with stakeholders [6,7]. Thus, firms with a high level of ESG initiatives can be easily identified and perceived by stakeholders. They effectively elicit positive stakeholder responses and gain heterogeneous resources, which enhances innovation [42]. It can be inferred that corporate 
environmental initiatives, social initiatives and governance initiatives positively affect innovative performance. In addition, stakeholder theory also suggests that the extent of the stakeholders' response to corporate behaviors is influenced by internal governance mechanisms and the external institutional environment [13]. A higher level of internal governance mechanisms mitigates the agency problem, which implies greater capabilities of managing the relationship with stakeholders and leveraging heterogeneous resources from them [57], while a high level of external institutional environment implies rigorous government policies and a relatively developed market environment, which further improves the effectiveness of internal governance mechanisms [58]. Therefore, in the process of exerting the effects of corporate social and environmental initiatives, internal governance mechanisms may provide the advantages to further elicit stakeholder responses and bring about the improvement of innovation. This suggests that corporate governance incentives play a moderating role in the relationship between social initiatives and innovative performance and in the relationship between environmental initiatives and innovative performance. In addition, the impacts of internal governance vary across different external institution environments [58]. It can be further argued that institutional development influences the moderating effect of corporate governance initiatives. According to the above-mentioned analyses, we constructed a corporate ESG model framework to examine the effects of individual aspects of corporate ESG initiatives, institutional development and their association with innovative performance for corporate sustainability shown as Figure 1.

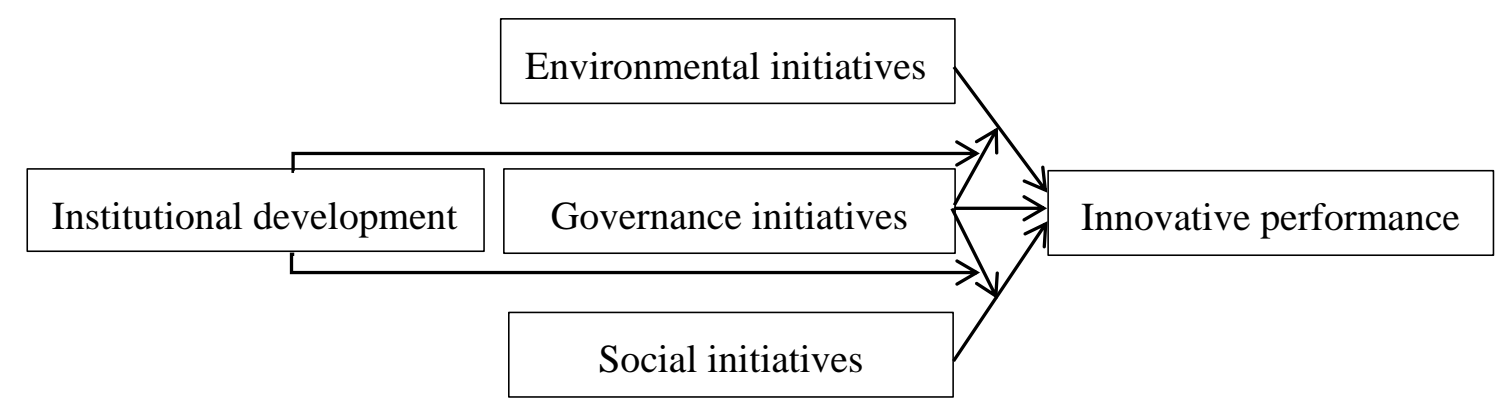

Figure 1. The conceptual corporate ESG model.

\subsection{Hypotheses}

\subsubsection{Corporate Environmental Initiatives and Innovative Performance}

Corporate environmental initiatives have been defined in the literature as the commitment of firms to contribute to the natural systems, including energy saving, emission reduction, garbage classification and resources recovery [8]. According to signal transfer theory, firms conducting environmental practices transfer a signal that they are willing to act altruistically on the issue of environmental production [7]. This positive signal enhances their corporate environmental reputation, elicits a stronger identification by stakeholders and thus promotes positive stakeholder responses, such as increasing their participation and cooperation [23]. In the process of business management, stakeholders play a facilitative and supportive role, and their support is seen as instrumental in obtaining necessary resources for sustainable development, especially for innovation activities that need heterogeneous resources as an input [13]. In addition, corporate environmental initiatives also serve as the desirable, proper or appropriate actions, in congruence with the expectations of institutions and stakeholders regarding environmental protection [41]. Based on legitimacy theory, it can be inferred that environmental initiatives promote the alignment of business entities and socially constructed systems with prevailing norms, values, beliefs and definitions, leading to the improvement of corporate environmental legitimacy [10]. Many scholars have demonstrated the importance of environmental legitimacy for firms to obtain resources for innovation [18,59]. Li, He, Liu et al. argued that corporate environmental behaviors promote stronger environmental legitimacy, which makes it easier to obtain consumers' responses and scarce knowledge [60]. DiMaggio and Powell 
argued that environmental legitimacy reduces the communication barrier between firms and their cooperative partners and extends the accessibility of their resources [61]. Therefore, environmental initiatives serving the environmental demands of stakeholders elicit positive stakeholder responses and lead to the obtainment of their heterogeneous resources in a way that positively enhances their innovative capabilities.

Hypothesis 1 (H1). Corporate environmental initiatives are positively related to innovative performance.

\subsubsection{Corporate Social Initiatives and Innovative Performance}

Corporate social initiatives refer to discretionary behaviors to meet the expectations of society beyond the immediate interests of a firm and its shareholders [8]. Similar to corporate environmental initiatives, corporate social initiatives act as good explanatory signals that serve the implicit claims of stakeholders and conform to social norms from the perspective of signal transfer theory. These signals are thrust into the media spotlight, which will arouse stakeholders' perception and identification, and thus help a firm establish reputational advantages over its competitors [19]. In general, firms with a high reputation subsequently utilize these advantages to generate stakeholder feedback and enhance their knowledge. This knowledge can be combined or transformed into valuable intangible resources, which provides a pathway to new products or new processes [62]. Thus, corporate social initiatives are considered to be an important strategic approach for firm innovation. Additionally, a line of works has applied the legitimacy theory in corporate social responsibility studies, which posit that corporate social initiatives have come to be perceived as a transparent and sociopolitically legitimate activity [18]. On one hand, corporate social initiatives help a firm gain the acceptance of stakeholders in terms of existing norms and laws. For example, a myriad of studies have shown the CSR results in different stakeholder outcomes (i.e., customer loyalty [63], employee satisfaction [64], investment intention [65]). These outcomes may encourage stakeholders to share their innovative knowledge assets with firms. On the other hand, corporate social initiatives help firms address the concerns of government and costly regulations, which results in the accumulation of political resources such as lower tax rates [21] and provides the protection of property rights [7]. Thus, it is reasonable to conclude that corporate social initiatives may be instrumental in obtaining stakeholder support or necessary political resources, which elevates firm innovation.

Hypothesis 2 (H2). Corporate social initiatives are positively related to innovative performance.

\subsubsection{Corporate Governance Initiatives and Innovative Performance}

Corporate governance initiatives denote the practices focused on stewardship toward corporate structure and a strategy for forging a common economic bond between managers and shareholders and decreasing the conflicts of interest between minority shareholders and majority shareholders $[8,66]$. Appropriate corporate governance mechanisms, including incentive-based governance and monitoring-based governance, may enhance the CEOs' or managers' sense of collective honor and organizational belonging, which will encourage them to engage in actions that will improve shareholder wealth and firm value [58]. First, the incentive-based governance, in the form of managerial equity ownership and managerial compensation, motivates managers to devote their best efforts to environmental and social practices. This strengthens the positive effects of environmental and social initiatives and promotes long-term innovative benefits [57]. On the one hand, offering higher salaries satisfies the essential material needs of managers and compensates for the time and opportunity costs which managers spend on environmental and social initiatives [58]. It brings about a stronger environmental and social awareness on the part of managers, and more initiatives to allocate and exploit the firm's resources from an environmental and social perspective. This is crucial to improving 
corporate reputation, maintaining organizational legitimacy and, further, leading to innovative profits. On the other hand, the equity ownership rights of managers increase their managerial discretion to arrange organizational behaviors, thereby amplifying their influence on the decisions of a firm [67]. In such situations, managers have more power to conduct environmental and social practices and exert their advantages to increase corporate reputation and legitimacy. This results in the increase of innovative resources. Second, the monitoring-based governance with the form of large outside shareholders, outsiders on a board and separation of CEO and chairpersons aims to ensure that managers treat shareholders equally $[57,66]$. The effect of monitoring-based governance depends on the information characteristic of management behaviors that is to be monitored [67]. In reality, many firms have begun to voluntarily disclose environmental and social responsibility information, which indicates that information asymmetry between shareholders or outside directors and managers will decrease [41]. Thus, under the high level of monitoring, the self-serving behaviors of managers will be limited and the stronger pressures will push them to fulfill corporate environmental and social responsibilities and to obey the laws and regulations. In addition, these managers will pay more attention to exerting their effects, such as building long-term and stable relationships, improving corporate reputation and maintaining organizational legitimacy, which benefits the obtaining of innovative resources. Thus, it can be inferred that corporate governance initiatives serve as a reference for environmental and social initiatives to generate reputation and legitimacy, which lead to benefits in innovation.

Hypothesis 3 (H3). Corporate governance initiatives are positively related to innovative performance.

Hypothesis 4a (H4a). Corporate governance initiatives positively moderate the relationship between environmental initiatives and innovative performance.

Hypothesis $4 \mathbf{b}(\mathbf{H} 4 \mathbf{b})$. Corporate governance initiatives positively moderate the relationship between social initiatives and innovative performance.

\subsubsection{The Moderating Role of Institutional Development}

Institutional development settings refer to the basic political conditions, social institutions and legal rules for corporate production and operation [58]. A higher level of institutional development refers to a competitive market environment, a high level of financial development, less government intervention, strong legal systems and a market for corporate control, which can restrict the residual rights of control of management and prevent rent appropriation by insiders. In essence, it further strengthens the effectiveness of corporate governance mechanisms [58]. First, a strong institutional development leaves less room for financing constraints and diverse options for corporate differentiation strategies [24]. In regions with a relatively developed economy, managers have great confidence in their decision-making due to the positive financial support, and they tend to effectively capitalize on the advantages of internal governance for individual interests by freely engaging in environmental-oriented or social-oriented behaviors. This leads to higher speeds in obtaining, accumulating and updating innovative knowledge from stakeholders. Second, one notable feature of strong institutional development is a low degree of government intervention [7]. Compared with firms in the lower government intervention regions, firms in the regions with strong government intervention will face the circumstances of a distorted market, inefficient resource allocation and corruption, which makes it more difficult for managers to adjust dynamically to suitable environmental or social strategies. This eventually weakens the incentive and monitoring effects of internal governance initiatives. Third, a strong institutional development leads to complete legal systems and strict transparency requirements. The regions with strong legal systems grant shareholders the right to discipline CEO or managers and to enforce contracts that limit the managers' private control. This further strengthens the monitoring role of internal governance initiatives and allows for environmental and social investment to be transformed into higher economic 
profits. Therefore, it can be argued that institutional development critically affects the extent to which a firm's internal governance initiatives can exert their full potential for creating innovative performance derived from environmental and social initiatives.

Hypothesis 5a (H5a). Institutional development increases the moderating effect of corporate governance initiatives on the relationship between environmental initiatives and innovative performance.

Hypothesis $\mathbf{5 b} \mathbf{b} \mathbf{H} \mathbf{5 b})$. Institutional development increases the moderating effect of corporate governance initiatives on the relationship between social initiatives and innovative performance.

\section{Methodology}

\subsection{Sample and Data Selection}

We selected the Chinese A-share listed firms at the Shanghai and Shenzhen stock exchanges from 2007 to 2017 as the unit of analysis. Corporate ESG initiatives information has been obtained from the Thomson Reuters ASSET4 database, which is regarded as a comprehensive platform that provides publicly transparent, objective, auditable, comparable and systematic economic ESG information [10]. The reliability and trustworthiness of these data sources for sustainable analysis have been identified by recent studies $[8,10]$. The innovation information was derived from the patent database of the State Intellectual and Patent Office of China (SIPO), the most authoritative database to disclose patent numbers, through manual retrieval and collection [68]. Corporate financial data and other corporate information stem from the China Stock Market and Accounting Research (CSMAR) database, which is the first high-precision database complying with international standards in China, designed by GTA information technology [8]. Institutional development data were computed using data from Chinese statistical yearbooks [58]. Due to the fewer Chinese listed firms at the Shanghai and Shenzhen stock exchanges evaluated by Thomson Reuters in 2007-2009, the initial sample is composed of 777 observations from 259 firms. After deleting financial firms and unsuitable firms such as the special treatment (ST) and particular transfer (PT) firms, as well as the observations that omitted variables (such as innovation data), the final sample consisted of 433 observations from 224 firms distributed across different industrial sectors, as follows: $48.46 \%$ manufacturing, $15.43 \%$ mining, $8.35 \%$ transportation, warehousing and postal services, $7.99 \%$ construction, $7.44 \%$ electricity, thermal, gas and water production and supply industries, and $12.33 \%$ from other sectors.

\subsection{Variables and Measurement}

\subsubsection{Innovative Performance}

The objective of improving a firm's innovative performance is critical for creating sustainable competitive advantages. In large parts of the leading literature, patent output is generally accepted as an appropriate quantitative indicator that stands for the innovative capability of a firm in terms of technology, processes and products [53]. Following the method of He and Wang [67] and Surroca, Tribó and Waddock [68], we employed the logarithm of patent counts as a proxy of innovative performance $(I P)$.

\subsubsection{Corporate ESG Initiatives}

The systematic ESG rating approach is designed to measure the corporate-relative ESG performance, commitment and effectiveness derived from a firm's annual report, which is useful to determine a firm's level of ESG initiatives [41]. ESG scores, ranging from 0 to 100, with 0 as the lowest score, consisted of three independent scores: E score, S score and G score, grouped into 10 categories and 178 different indicators. Following Duque-Grisales and Aguilera-Caracuel [8], we measured 
environmental initiatives, social initiatives and governance initiatives as the E score, S score and G score, respectively. The description of ESG initiatives is shown in Table 2.

Table 2. Description of ESG initiatives.

\begin{tabular}{|c|c|c|c|c|c|}
\hline Variable & Measure & Description & Category & Indicators & Weight \\
\hline \multirow{3}{*}{$\begin{array}{l}\text { Environmental } \\
\text { initiatives }(E I)\end{array}$} & \multirow{3}{*}{ E score } & $\begin{array}{l}\text { (1) Reduce the usage of materials, energy } \\
\text { or water }\end{array}$ & Resource use & 19 & $11 \%$ \\
\hline & & (2)Reduce environmental emission & Emissions & 22 & $12 \%$ \\
\hline & & $\begin{array}{l}\text { (3) Reduce environmental costs or burdens by } \\
\text { new environmental technologies }\end{array}$ & $\begin{array}{l}\text { Environmental } \\
\text { innovation }\end{array}$ & 20 & $11 \%$ \\
\hline \multirow{3}{*}{$\begin{array}{c}\text { Social } \\
\text { initiatives }(S I)\end{array}$} & \multirow{3}{*}{ S score } & & Workforce & 29 & $16 \%$ \\
\hline & & $\begin{array}{l}\text { (2) Achieve fairness toward the workforce, } \\
\text { respect the fundamental human rights } \\
\text { conventions }\end{array}$ & Human rights & 8 & $4.5 \%$ \\
\hline & & (3) Be a good citizen & Community & 14 & $8 \%$ \\
\hline \multirow{4}{*}{$\begin{array}{c}\text { Governance } \\
\text { initiatives }(G I)\end{array}$} & \multirow{4}{*}{ G score } & (4) Produce quality goods and services & $\begin{array}{l}\text { Product } \\
\text { responsibility }\end{array}$ & 12 & $7 \%$ \\
\hline & & $\begin{array}{c}\text { (1)Follow best practice corporate governance } \\
\text { principles }\end{array}$ & Management & 34 & $19 \%$ \\
\hline & & $\begin{array}{l}\text { (2) Equal treatment of shareholders and the } \\
\text { use of anti-takeover devices }\end{array}$ & Shareholders & 12 & $7 \%$ \\
\hline & & $\begin{array}{l}\text { (3)Integrate ESG dimensions into } \\
\text { decision-making }\end{array}$ & CSR strategy & 8 & $4.5 \%$ \\
\hline
\end{tabular}

\subsubsection{Institutional Development}

Market development is a proxy of institutional development to explain the extent of institutional settings in Chinese provinces, municipalities and autonomous regions [58]. Following the lead of previous studies, we adopted the ratio of a province's GDP to its government's budget to measure institutional development (ID) [58]. The higher level of market development reflects the rigorous government policies to organize firms and means the higher market capability to allocate provincial resources.

\subsubsection{Control Variables}

Firm leverage $(L E V)$ reflects a firm's financial barrier measured by the ratio of total debt to total equity. Return on assets $(R O A)$ reflects the profitable capability of a firm, measured by the ratio of net income to total assets. Research \& development intensity $(R \mathcal{E} D)$ reflects the input of innovation, which is measured as $R \mathcal{E} D$ expenditures divided by sales. Capital intensity $(C I)$ reflects the degree of necessary investment computed as a ratio of the total value of assets to the sales revenue.

\subsection{Estimation Model}

In line with the leading literature [8,21], a hierarchical regression analysis was used to test the hypotheses. To resolve the potential endogeneity bias, a 1-year lag for innovative performance was used in the estimation models. In addition, industry and year fixed effects were controlled to decrease the shock of any unobserved industry characteristics or macroeconomic factors.

$$
\begin{aligned}
& I P_{i, t+1}=\alpha+\beta_{1} E I_{i, t}+\beta_{2} S I_{i, t}+\beta_{3} G I_{i, t}+\beta_{4} I D_{i, t}+\beta_{5} E I_{i, t} * G I_{i, t}+\beta_{6} S I * G I+\beta_{7} E I_{i, t} * I D_{i, t}+ \\
& \beta_{8} S I_{i, t} * I D_{i, t}+\beta_{9} G I_{i, t} * I D_{i, t}+\beta_{10} E I_{i, t} * G I_{i, t} * I D_{i, t}+\beta_{11} S I_{i, t} * G I_{i, t} * I D_{i, t}+\beta_{12} \text { controls }_{i, t}+\varepsilon
\end{aligned}
$$

where $i$ refers to the firm and $t$ refers to the time. $I P_{i, t+1}$ denotes the degree of innovation of firm $i$ in year $t+1$. $E I_{i, t}, S I_{i, t}, G I_{i, t}$ denotes the level of environmental initiatives, social initiatives and governance initiatives of firm $i$ in year $t$ and $I D_{i, t}$ denotes the level of institutional development of firm $i$ in year $t$. Controls include firm leverage, return on assets, $R \mathcal{E} D$ intensity and capital intensity. $\alpha$ is the intercept term and $\varepsilon$ is the random disturbance term of these models. $\beta_{1}, \beta_{2}$ and $\beta_{3}$ are the slope coefficients 
of $E I$, $S I$ and $G I$, respectively, and $\beta_{4}-\beta_{11}$ are the coefficients of interactive variables. $B_{12}$ refers to the coefficients of control variables.

\section{Results}

\subsection{Descriptive Statistics and Correlations Analysis}

Table 3 presents the descriptive statistics of variables including mean, standard deviation (SD) as well as Pearson correlations. The value of innovative performance for the whole sample ranging from 0 to 5636 with a mean of 325.594 indicates that firm innovation is highly skewed, and the differences are enormous among variety firms. The average scores of ESG initiatives are 40.168, 30.690 and 49.386, where the governance pillar is the highest, followed by the environmental pillar and the social pillar. This shows that the environmental and social responsibility awareness of firms is relatively low. The results also show that corporate ESG initiatives are significantly correlated with innovative performance. In addition, the bivariate correlations among ESC initiatives, institutional development and control variables are fairly low, and the maximum Variance Influence Factor (VIF) is 2.603 (social initiatives), below the threshold of 10.00, which indicates that the problem of multicollinearity may be limited.

Table 3. Descriptive statistics and Pearson correlations matrix.

\begin{tabular}{cccccccccccc}
\hline \multicolumn{2}{l}{ Variables } & Mean & SD & $\mathbf{1}$ & $\mathbf{2}$ & $\mathbf{3}$ & $\mathbf{4}$ & $\mathbf{5}$ & $\mathbf{6}$ & $\mathbf{7}$ & $\mathbf{8}$ \\
\hline 1 & $I P$ & 325.594 & 836.58 & 1 & & & & \\
2 & $E I$ & 40.168 & 20.531 & $0.225^{* * *}$ & 1 & & & & \\
3 & $S I$ & 30.690 & 15.523 & $0.165^{* * *}$ & $0.710^{* * *}$ & 1 & & & & \\
4 & $G I$ & 49.386 & 18.486 & $0.182^{* * *}$ & $0.464^{* * *}$ & $0.483^{* * *}$ & 1 & & & \\
5 & $I D$ & 7.845 & 2.761 & $-0.123^{* * *}$ & $-0.291^{* * *}$ & $-0.296^{* * *}$ & $-0.302^{* * *}$ & 1 & & \\
6 & $L E V$ & 0.557 & 0.181 & $0.111^{* * *}$ & $-0.073^{*}$ & 0.005 & 0.028 & $-0.090^{* *}$ & 1 & \\
7 & $R O A$ & 0.051 & 0.059 & -0.064 & -0.046 & $-0.072^{*}$ & $-0.086^{* *}$ & $0.119^{* * *}$ & $-0.597^{* * *}$ & 1 \\
8 & $R E D$ & 2.900 & 3.859 & -0.026 & 0.015 & 0.007 & $-0.122^{* *}$ & $0.099^{* *}$ & $-0.211^{* * *}$ & $0.097^{* *}$ & 1 \\
9 & $C I$ & 2.420 & 2.422 & $-0.165^{* * *}$ & $-0.103^{* *}$ & -0.064 & -0.026 & -0.082 & 0.082 & $-0.090^{* *}-0.042$ & 1 \\
\hline
\end{tabular}

$N=433^{*} p<0.1^{* *} p<0.05^{* * *} p<0.01$.

\subsection{Empirical Results}

Following the previous research, we evaluated the relationships among corporate ESG initiatives, institutional development and innovative performance using the hierarchical regression analysis and ordinary least squares regression models. Table 4 shows the regression results of these hypotheses, and the values of adjusted $R^{2}$ and F-value are acceptable for all constructed models. Model 1 reports the effects of firm-level control variables. The results of Model 2, Model 3 and Model 4 show that corporate environmental initiatives, social initiatives and governance initiatives have positive and significant relationships with innovative performance $(\beta=0.214, P<0.01 ; \beta=0.119, P<0.05 ; \beta=0.151$, $P<0.01)$. Therefore, Hypothesis 1 , Hypothesis 2 and Hypothesis 3 are supported.

In order to investigate the moderating effect of governance initiatives in the relationship between environmental initiatives and innovative performance, as well as the relationship between social initiatives and innovative performance (Hypothesis $4 \mathrm{a}$ and Hypothesis $4 \mathrm{~b}$ ), we adopted mean-centered constructs on variables to avoid the problem of multicollinearity bias according to Friedrich [69]. The results of Model 5 show that the coefficient of the interaction term between environmental initiatives and governance initiatives is significant and positive $(\beta=0.157, P<0.01)$, which indicates that governance initiatives play a moderating role in the relationship between environmental initiatives and innovative performance. However, as shown in Model 6, the coefficient of the interaction term between social initiatives and governance initiatives is not significant $(\beta=0.031$, n.s.). The moderating effect of governance initiatives on the relationship between social initiatives and innovative performance is not supported by the empirical results in the case of corporate internal governance mechanisms. A summary of the testing results is shown in Table 5.

In addition, we further analyzed the contextual effects of institutional development on the relationship between ESG initiatives and innovative performance, especially the context effects on the 
moderating effect of governance initiatives. The results of Model 7 show that the coefficient of the interaction term between environmental initiatives and governance initiatives $(\beta=0.248, P<0.01)$ and the coefficient of the interaction term between social initiatives and governance initiative $(\beta=0.161$, $P<0.05)$ are positive and significant when considering internal and external governance mechanisms simultaneously. Hypotheses $4 \mathrm{a}$ and $4 \mathrm{~b}$ are accepted. Furthermore, the positive and significant three-way interactions among environmental initiatives, governance initiatives and institutional development $(\beta=0.101, P<0.1)$ and the three-way interactions among social initiatives, governance initiatives and institutional development $(\beta=0.129, P<0.01)$ show that the impact of institutional development on the moderation of governance initiatives is significant. Therefore, Hypotheses $5 \mathrm{a}$ and $5 \mathrm{~b}$ are supported.

Table 4. Regression analysis results.

\begin{tabular}{|c|c|c|c|c|c|c|c|}
\hline & M1 & M2 & M3 & M4 & M5 & M6 & M7 \\
\hline$E I$ & & $\begin{array}{c}0.214^{* * *} \\
(4.568)\end{array}$ & & & $\begin{array}{c}0.147^{* * *} \\
(2.785)\end{array}$ & & $\begin{array}{c}0.171 \text { ** } \\
(2.411)\end{array}$ \\
\hline$S I$ & & & $\begin{array}{c}0.119^{* *} \\
(2.521)\end{array}$ & & & $\begin{array}{c}0.051 \\
(0.910)\end{array}$ & $\begin{array}{l}0.059 * \\
(1.982)\end{array}$ \\
\hline GI & & & & $\begin{array}{c}0.151^{* * *} \\
(3.190)\end{array}$ & $\begin{array}{c}0.119 * * \\
(0.119)\end{array}$ & $\begin{array}{c}0.136^{* *} \\
(2.321)\end{array}$ & $\begin{array}{c}0.129^{* *} \\
(2.102)\end{array}$ \\
\hline$E I^{*} G I$ & & & & & $\begin{array}{c}0.157^{* * *} \\
(3.246)\end{array}$ & & $\begin{array}{c}0.248^{* * *} \\
(3.500)\end{array}$ \\
\hline$S I^{*} G I$ & & & & & & $\begin{array}{c}0.031 \\
(0.604)\end{array}$ & $\begin{array}{l}0.161^{* *} \\
(2.084)\end{array}$ \\
\hline$I D$ & & & & & & & $\begin{array}{c}-0.060 \\
(-1.170)\end{array}$ \\
\hline$E I^{*} I D$ & & & & & & & $\begin{array}{c}0.070 \\
(1.003)\end{array}$ \\
\hline$S I^{*} I D$ & & & & & & & $\begin{array}{c}0.056 \\
(0.821)\end{array}$ \\
\hline$G I^{*} I D$ & & & & & & & $\begin{array}{c}-0.060 \\
(-1.120)\end{array}$ \\
\hline$E I^{*} G I^{*} I D$ & & & & & & & $\begin{array}{l}0.101 \text { * } \\
(1.770)\end{array}$ \\
\hline$S I^{*} G I^{*} I D$ & & & & & & & $\begin{array}{l}0.129^{*} \\
(1.747)\end{array}$ \\
\hline LEV & $\begin{array}{c}0.179 * * * \\
(2.925)\end{array}$ & $\begin{array}{c}0.207^{* * *} \\
(3.441)\end{array}$ & $\begin{array}{c}0.180 * * * \\
(2.969)\end{array}$ & $\begin{array}{c}0.171^{* * *} \\
(2.819)\end{array}$ & $\begin{array}{c}0.199 * * * \\
(3.336)\end{array}$ & $\begin{array}{c}0.172^{* * *} \\
(2.843)\end{array}$ & $\begin{array}{c}0.197^{* * *} \\
(3.185)\end{array}$ \\
\hline$R O A$ & $\begin{array}{c}0.030 \\
(0.501)\end{array}$ & $\begin{array}{c}0.061 \\
(1.029)\end{array}$ & $\begin{array}{c}0.042 \\
(0.707)\end{array}$ & $\begin{array}{c}0.041 \\
(0.680)\end{array}$ & $\begin{array}{c}0.071 \\
(1.210)\end{array}$ & $\begin{array}{c}0.046 \\
(0.772)\end{array}$ & $\begin{array}{c}0.077 \\
(1.302)\end{array}$ \\
\hline$R \mathcal{E D}$ & $\begin{array}{c}0.104^{* * *} \\
(2.976)\end{array}$ & $\begin{array}{c}0.104^{* * *} \\
(2.993)\end{array}$ & $\begin{array}{c}0.102 * * * \\
(2.948)\end{array}$ & $\begin{array}{c}0.119^{* * *} \\
(3.399)\end{array}$ & $\begin{array}{c}0.137 * * * \\
(3.772)\end{array}$ & $\begin{array}{c}0.118^{* * *} \\
(3.366)\end{array}$ & $\begin{array}{c}0.156^{* * *} \\
(3.175)\end{array}$ \\
\hline$C I$ & $\begin{array}{c}-0.130 * * * \\
(-2.747)\end{array}$ & $\begin{array}{c}-0.106^{* *} \\
(-2.271)\end{array}$ & $\begin{array}{c}-0.123^{* *} \\
(-2.595)\end{array}$ & $\begin{array}{c}-0.133 * * * \\
(-2.834)\end{array}$ & $\begin{array}{l}-0.106^{* *} \\
(-2.295)\end{array}$ & $\begin{array}{c}-0.128^{* * *} \\
(-2.713)\end{array}$ & $\begin{array}{l}-0.102 \text { ** } \\
(-2.209)\end{array}$ \\
\hline Year & Included & Included & Included & Included & Included & Included & Included \\
\hline Industry & Included & Included & Included & Included & Included & Included & Included \\
\hline $\operatorname{Adj} R^{2}$ & 0.043 & 0.088 & 0.057 & 0.065 & 0.114 & 0.069 & 0.150 \\
\hline Fvalue & $4.821^{* * *}$ & $8.210^{* * *}$ & $5.176^{* * *}$ & $5.975^{* * *}$ & $7.778^{* * *}$ & $4.519^{* * *}$ & $4.925^{* * *}$ \\
\hline
\end{tabular}

Table 5. Summary of testing results.

\begin{tabular}{cccc}
\hline Hypothesis & Relationship & Direction & Result \\
\hline $\mathrm{H} 1$ & $E I-I P$ & Positive & Supported \\
$\mathrm{H} 2$ & SI-IP & Positive & Supported \\
$\mathrm{H} 3$ & GI-IP & Positive & Supported \\
$\mathrm{H} 4 \mathrm{a}$ & The moderating role of GI in link EI-IP & Positive & Supported \\
$\mathrm{H} 4 \mathrm{~b}$ & The moderating role of GI in link SI-IP & Positive & Not supported \\
$\mathrm{H} 5 \mathrm{a}$ & $I D$ influences the moderating effect of GI on link EI-IP & Positive & Supported \\
$\mathrm{H} 5 \mathrm{~b}$ & $I D$ influences the moderating effect of GI on link SI-IP & Positive & Supported \\
\hline
\end{tabular}

To better interpret these results, we show the moderating effect figures (Figures 2-5) in line with the method of Aiken and West [70]. Figure 2; Figure 3 affirm the moderating role of governance 
initiatives in the relationship between environmental initiatives and innovative performance and in the relationship between social initiatives and innovative performance. We can clearly see that these relationships are more positive under the high level of governance initiatives. In addition, as we expected, these positive relationships are relatively strengthened at the high levels of institutional development shown in Figures 4 and 5. This indicates the moderating effect of governance initiatives under a high level of institutional development.

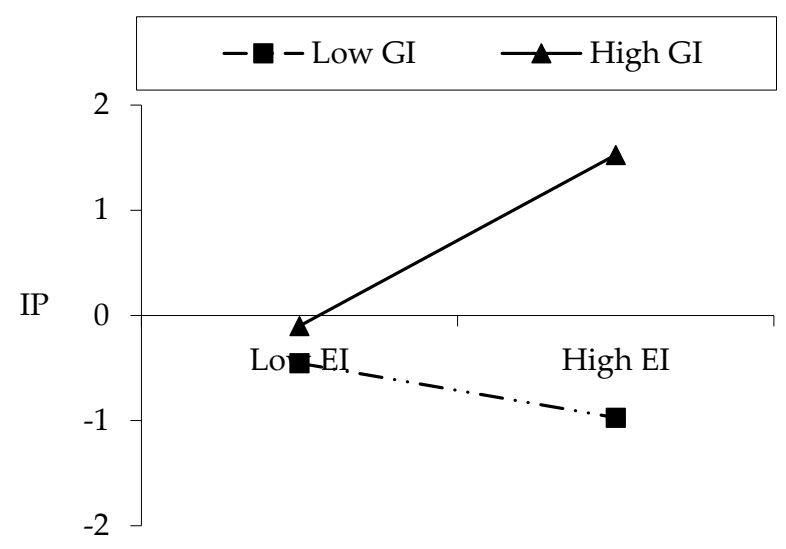

Figure 2. Moderating effects of governance initiatives on the environmental initiatives-innovative performance relationship.

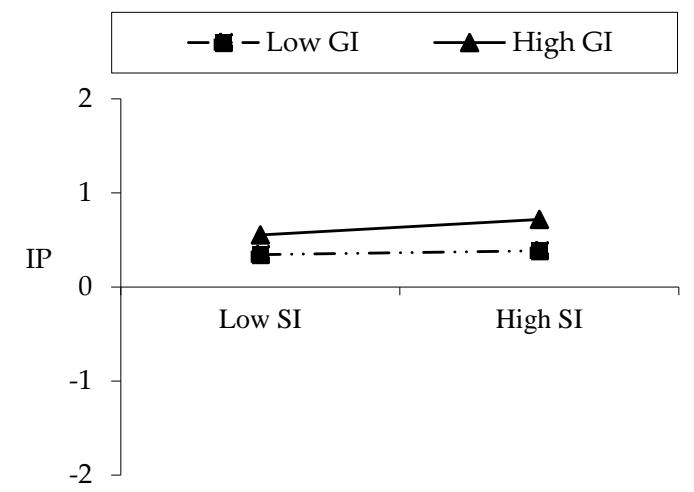

Figure 3. Moderating effects of governance initiatives on the social initiatives-innovative performance relationship.

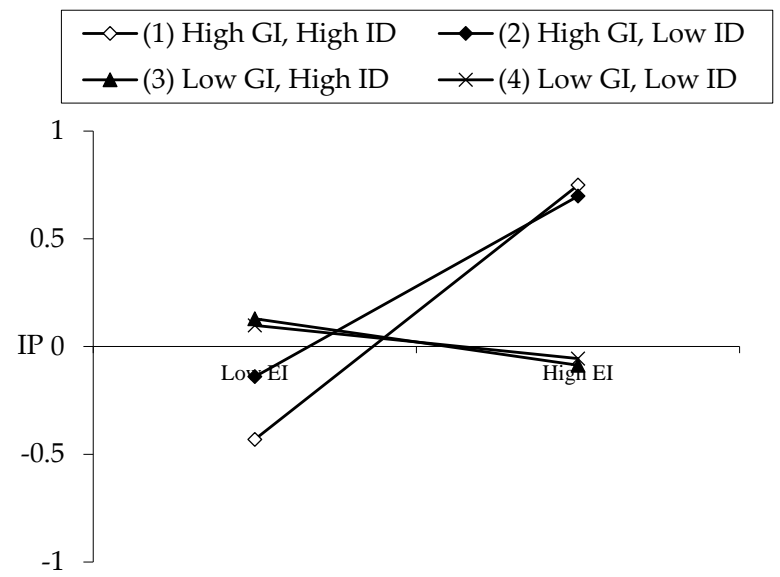

Figure 4. Moderating effects of institutional development on the environmental initiatives-innovative performance relationship. 


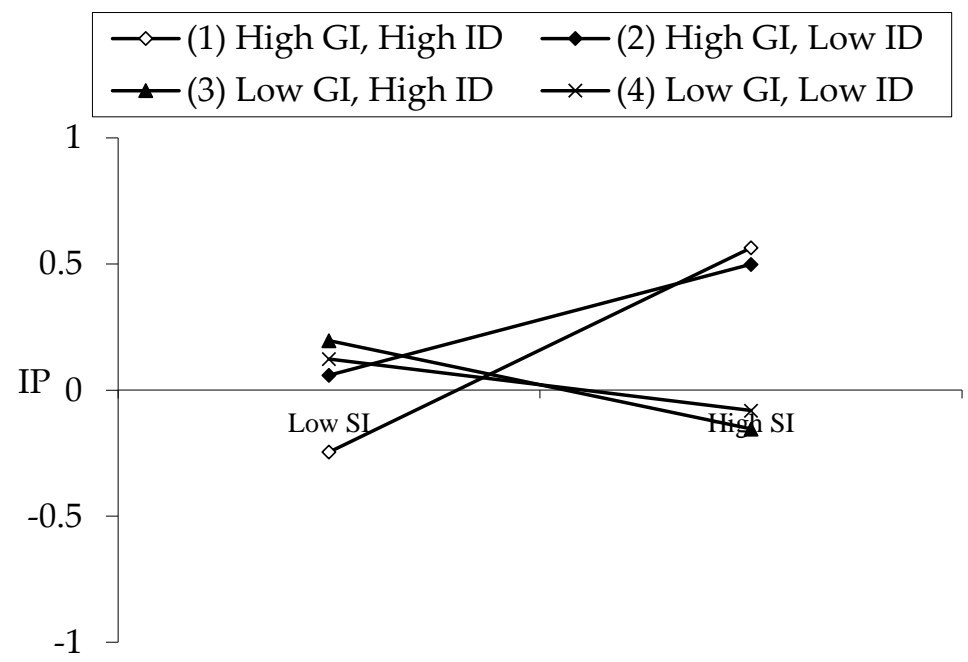

Figure 5. Moderating effects of institutional development on the social initiatives-innovative performance relationship.

\subsection{Robustness Test}

In order to avoid the influence of the measures of variables on the regression results, we conducted different measurements to test robustness. We replaced the numbers of patent citation as an alternative to innovative performance [67], $R \mathcal{E} D$ expenditure as an alternative to $R \mathcal{E} D$ intensity [67] and marketization index as an alternative to institutional development [46], to test the estimation models. The regression results were qualitatively unchanged and are shown in Table 6.

Table 6. Robustness test models.

\begin{tabular}{|c|c|c|c|c|c|c|}
\hline & M1 & M2 & M3 & M4 & M5 & M6 \\
\hline$E I$ & $0.211^{* * *}$ & & & $0.194^{* * *}$ & & $0.305^{* * *}$ \\
\hline SI & & $0.114^{* *}$ & & & 0.101 * & $0.069 *$ \\
\hline GI & & & $0.038^{*}$ & 0.040 * & 0.013 & 0.095 * \\
\hline$I D$ & & & & & & -0.111 \\
\hline$E I^{*} G I$ & & & & $0.122^{* *}$ & & $0.207^{* *}$ \\
\hline$S I^{*} G I$ & & & & & 0.043 * & $0.006^{*}$ \\
\hline$E I^{*} I D$ & & & & & & -0.064 \\
\hline$S I^{*} I D$ & & & & & & -0.085 \\
\hline$G I^{*} I D$ & & & & & & -0.160 \\
\hline$E I^{*} S I^{*} I D$ & & & & & & 0.125 * \\
\hline$G I^{*} S I^{*} I D$ & & & & & & $0.141^{*}$ \\
\hline Controls & Included & Included & Included & Included & Included & Included \\
\hline $\operatorname{Adj} R^{2}$ & 0.116 & 0.089 & 0.079 & 0.130 & 0.090 & 0.269 \\
\hline Fvalue & $11.215^{* * *}$ & $8.325^{* * *}$ & $7.294^{* * *}$ & $9.122^{* * *}$ & $6.032 * * *$ & $5.699 * * *$ \\
\hline
\end{tabular}

\section{Discussion and Conclusions}

The results denote that corporate environmental initiatives, social initiatives and governance initiatives have direct positive impacts on innovative performance. This indicates that corporate ESG initiatives are characterized by positive signal and legitimate image effects, which will increase stakeholders' trust, elicit their response and lead to the obtainment of their heterogeneous resources, thereby resulting in firm innovation. These conclusions are aligned with the research of Yoon, Lee and Byun [10], Duque-Grisales and Aguilera-Caracuel [8], and Xie, Nozawa, Yagi et al., [41] which confirmed the positive effects of ESG initiatives from the viewpoint of signal transfer theory and legitimacy theory. 
This study explores the interactive effect of different dimensions of ESG initiatives to investigate the contingency of positive signals and legitimate images caused by individual ESG initiatives. It finds that corporate governance initiatives play moderating roles in the relationship between environmental initiatives and innovative performance and in the relationship between social initiatives and innovative performance. This indicates that in firms with high-level corporate governance initiatives, the positive signal and legitimate image caused by environmental and social initiatives will further increase stakeholders' responses, resulting in a high innovative capability, whereas in firms with low-level corporate governance initiatives, the positive effects of environmental and social initiatives will weaken. The results are consistent with those of previous studies, which confirm that internal governance mechanisms reduce agency costs and broaden the positive effects of suitable corporate strategies [57].

In addition, this study reaffirms these findings and arguments by exploring the contingent effect of institutional development. It also shows that different levels of institutional development influence the effects of internal governance initiatives. The high-level external governance circumstances strengthen the moderating effect of governance initiatives on the relationship between environmental initiatives and innovative performance and in the relationship between social initiatives and innovative performance.

\subsection{Theoretical Contributions and Managerial Implications}

This study has made meaningful theoretical contributions. First, it extends corporate sustainability studies by enhancing the perception of the relationships among corporate environmental, social, governance and economic dimensions. Previous studies focus on the effects of ESG initiatives on economic outcomes from the perspective of financial performance or marketing performance $[8,10,41]$. Few of them pay attention to the relationship between ESG initiatives and innovative performance, thus ignoring the hidden effects of different aspects of ESG initiatives. This study addresses this gap and examines the individual effects of ESG initiatives on innovative performance separately, which helps build a theoretical link between corporate ESG initiatives and innovative outcomes in a more fine-grained manner. Second, this study represents an important addition to ESG literature by further analyzing the interactive effects of ESG initiatives. It indicates that corporate governance initiatives play a moderating role in the relationship between environmental initiatives and innovative performance and in the relationship between social initiatives and innovative performance. As far we know, we may be among the first to identify and empirically substantiate the moderating effects of corporate governance initiatives, which opens a black box with regard to the relations of the three dimensions of corporate ESG initiatives. Third, this study provides a contribution to the literature on corporate governance by providing additional empirical evidence on how to influence the effectiveness of corporate governance initiatives. It builds on the conclusion drawn by previous studies that positive corporate governance effects are contingent not only on corporate internal factors (e.g., firm risk and strategic complexity), but also on the institutional development. Additionally, this study contributes further to innovation research by showing that the necessity for a "fit" between corporate ESG initiatives and institutional development is an important influential factor for firm innovation.

This study also presents relevant management implications. First, the finding that a firm is better at improving innovative performance through corporate ESG initiatives indicates the need to consider corporate sustainability when devising a competitive strategy. Firms must be committed to corporate ESG initiatives, which are decisive for a win-win situation in society and the economy simultaneously. Second, this study provides guidelines for firms on how to build corporate governance mechanisms to improve the economic outcomes of strategic decisions. Firms should be conscious of the importance of corporate governance initiatives and take advantage of the positive signal transmission which corporate environmental initiatives and social initiatives bring. Third, firms should flexibly choose different corporate governance plans to strengthen the effectiveness of corporate environmental initiatives and social initiatives according to different forms of institutional development. Keeping the fit between internal governance mechanisms and institutional development has therefore been considered crucial for corporate sustainability. 


\subsection{Limitations and Future Research}

There are several limitations that need to be considered in future research. The generalizability of this research is limited because the results are based on a sample listed in the Shanghai and Shenzhen stock exchanges. Future research could explore whether these results are valid in the case of developed countries or international markets, because the strategic choice and innovation capabilities of firms are influenced by the dynamism of the institutional environment. Second, this study selects ESG scores from the Thomson Reuters ASSET4 database to measure corporate ESG initiatives. Future scholars could investigate ESG scores from the MSCI ESG KLD STATS database or the Dow Jones Sustainability Indices or other measures on proxies of corporate ESG initiatives.

\subsection{Concluding Remarks}

This study investigates the impact of corporate ESG initiatives on innovative performance for corporate sustainability, especially considering the different degrees of institutional development, and proposes an empirical examination of Chinese A-share listed firms from 2007 to 2017. Using the method of hierarchical regression analysis, the empirical results have confirmed that corporate environmental initiatives, social initiatives and governance initiatives have direct positive influences on innovative performance for corporate sustainability. In addition, the study also shows that corporate governance initiatives play a moderating role on the relationship between environmental initiatives and innovative performance and in the relationship between social initiatives and innovative performance. Furthermore, it indicates that the moderating effects of corporate governance initiatives are influenced by different degrees of institutional development.

Author Contributions: Conceptualization, Q.Z. and L.L.; methodology and formal analysis, Q.Z.; original draft preparation, Q.Z.; review and editing, L.L.; supervision, W.W. All authors have read and agreed to the published version of the manuscript.

Funding: This research was funded by National Natural Science Foundation of China $(71472055,71272175)$, the National Social Science Foundation of China (16AZD0006), the Heilongiiang Philosophy and Social Science Research Project (19GLB087), China, the Fundamental Research Funds for the Central Universities (HIT.NSRIF.2019033), and the humanities and social sciences project of Ministry of Education in China (20YJC630090).

Conflicts of Interest: The authors declare no conflicts of interest.

\section{Abbreviations}

$\begin{array}{ll}\text { Corporate ESG initiatives } & \text { Corporate environmental, social and governance initiatives } \\ I P & \text { innovative performance } \\ I D & \text { Institutional development } \\ L E V & \text { Firm leverage } \\ R O A & \text { Return on assets } \\ R \mathcal{E D} \text { intensity } & \text { Research and development intensity } \\ C I & \text { Capital intensity }\end{array}$

\section{References}

1. Caiado, R.G.G.; de Freitas Dias, R.; Mattos, L.V.; Quelhas, O.L.G.; Leal Filho, W. Towards Sustainable Development through the Perspective of Eco-efficiency-A systematic literature review. J. Clean. Prod. 2017, 165, 890-904. [CrossRef]

2. Hahn, T.; Figge, F.; Pinkse, J.; Preuss, L. A Paradox Perspective on Corporate Sustainability: Descriptive, Instrumental, and Normative Aspects. J. Bus. Ethics 2018, 148, 235-248. [CrossRef]

3. Landrum, N.E.; Ohsowski, B. Identifying Worldviews on Corporate Sustainability: A Content Analysis of Corporate Sustainability Reports. Bus. Strategy Environ. 2017, 27, 128-151. [CrossRef]

4. Aras, G.; Tezcan, N.; Kutlu Furtuna, O. The Value Relevance of Banking Sector Multidimensional Corporate Sustainability Performance. Corp. Soc. Responsib. Environ. Manag. 2018, 25, 1062-1073. [CrossRef]

5. Lloret, A. Modeling Corporate Sustainability Strategy. J. Bus. Res. 2016, 69, 418-425. [CrossRef] 
6. Dowell, G.W.S.; Muthulingam, S. Will Firms Go Green if it Pays? The Impact of Disruption, Cost, and External Factors on the Adoption of Environmental Initiatives. Strateg. Manag. J. 2017, 38, 1287-1304. [CrossRef]

7. Lo, K.Y.; Kwan, C.L. The Effect of Environmental, Social, Governance and Sustainability Initiatives on Stock Value-Examining Market Response to Initiatives Undertaken by Listed Companies. Corp. Soc. Responsib. Environ. Manag. 2017, 24, 606-619. [CrossRef]

8. Duque-Grisales, E.; Aguilera-Caracuel, J. Environmental, Social and Governance (ESG) Scores and Financial Performance of Multilatinas: Moderating Effects of Geographic International Diversification and Financial Slack. J. Bus. Ethics 2019, 1-20. [CrossRef]

9. Ting, I.W.K.; Azizan, N.A.; Bhaskaran, R.K.; Sukumaran, S.K. Corporate Social Performance and Firm Performance: Comparative Study among Developed and Emerging Market Firms. Sustainability 2019, 12, 26. [CrossRef]

10. Yoon, B.; Lee, J.; Byun, R. Does ESG Performance Enhance Firm Value? Evidence from Korea. Sustainability 2018, 10, 3635. [CrossRef]

11. Wei, L.; Wenjun, W.; Sulkowski, A.; Wu, J. The relationships between environmental management, firm value and other firm attributes: Evidence from Chinese manufacturing industry. Int. J. Environ. Sustain. Dev. 2011, 10, 78-95.

12. Sulkowski, A.J.; Parashar, S.; Wei, L. Corporate responsibility reporting in china, India, Japan, and the west: One mantra does not fit all. New Eng. L. Rev. 2007, 42, 787.

13. Vos, J.F.J. Corporate social responsibility and the Identification of Stakeholders. Corp. Soc. Responsib. Environ. Manag. 2003, 10, 141-152. [CrossRef]

14. Sulkowski, A.J.; Edwards, M.; Freeman, R.E. Shake your stakeholder: Firms leading engagement to cocreate sustainable value. Organ. Environ. 2018, 31, 223-241. [CrossRef]

15. Odriozola, M.D.; Baraibar-Diez, E. Is Corporate Reputation Associated with Quality of CSR Reporting? Evidence from Spain. Corp. Soc. Responsib. Environ. Manag. 2017, 24, 121-132. [CrossRef]

16. Hughey, C.J.; Sulkowski, A.J. More disclosure = better CSR reputation? An examination of CSR reputation leaders and laggards in the global oil \& gas industry. J. Acad. Bus. Econ. 2012, 12, $24-34$.

17. Chang, C.-P. The Relationships among Corporate Social Responsibility, Corporate Image and Economic Performance of High-tech Industries in Taiwan. Qual. Quant. 2007, 43, 417-429. [CrossRef]

18. Servaes, H.; Tamayo, A. The Impact of Corporate Social Responsibility on Firm Value: The Role of Customer Awareness. Manag. Sci. 2013, 59, 1045-1061. [CrossRef]

19. Flammer, C.; Luo, J. Corporate Social Responsibility as an Employee Governance Tool: Evidence from a Quasi-Experiment. Strateg. Manag. J. 2017, 38, 163-183. [CrossRef]

20. Walsh, C.; Sulkowski, A.J. A greener company makes for happier employees more so than does a more valuable one: A regression analysis of employee satisfaction, perceived environmental performance and firm financial value. Interdiscip. Environ. Rev. 2010, 11, 274-282. [CrossRef]

21. Li, Y.; Gong, M.; Zhang, X.-Y.; Koh, L. The Impact of Environmental, Social, and Governance Disclosure on Firm Value: The Role of CEO Power. Br. Account. Rev. 2018, 50, 60-75. [CrossRef]

22. Sulkowski, A.; White, S. Financial performance, pollution measures, and the propensity to use corporate responsibility reporting: Implications for business and legal scholarship. SSRN Electron. J. 2009. [CrossRef]

23. Su, W.; Peng, M.W.; Tan, W.; Cheung, Y.-L. The Signaling Effect of Corporate Social Responsibility in Emerging Economies. J. Bus. Ethics 2014, 134, 479-491. [CrossRef]

24. Singh, R.; Bakshi, M.; Mishra, P. Corporate Social Responsibility: Linking Bottom of the Pyramid to Market Development? J. Bus. Ethics 2014, 131, 361-373. [CrossRef]

25. Woodell, S. Blueprint for survival. Nature 1972, 235, 179. [CrossRef]

26. Porter, M.E.; Millar, V.E. How Information Gives You Competitive Advantage. Harv. Bus. Rev. 1985, 63, 149-160.

27. WCED, S.W.S. World Commission on Environment and Development. Our Common Future 1987, $17,1-91$. Available online: https://sustainabledevelopment.un.org/milestones/wced (accessed on 17 April 2020).

28. Elkington, J. Cannibals with Forks: The TBL of the 21st Century Business; Capstone: Oxford, UK, 1997.

29. Elkington, J. Partnerships from Cannibals with Forks: The Triple Bottom Line of 21st-century business. Environ. Qual. Manag. 1998, 8, 37-51. [CrossRef] 
30. Lozano, R. A Holistic Perspective on Corporate Sustainability Drivers. Corp. Soc. Responsib. Environ. Manag. 2015, 22, 32-44. [CrossRef]

31. Lélé, S.M. Sustainable Development: A Critical Review. World Dev. 1991, 19, 607-621. [CrossRef]

32. Shrivastava, P. The Role of Corporations in Achieving Ecological Sustainability. Acad. Manag. Rev. 1995, 20, 936-960. [CrossRef]

33. Hueting, R.; Reijnders, L. Sustainability is an Objective Concept. Ecol. Econ. 1998, 27, 139-148.

34. Banerjee, S.B. Who Sustains Whose Development? Sustainable Development and the Reinvention of Nature. Organ. Stud. 2003, 24, 143-180. [CrossRef]

35. Bansal, P. Evolving Sustainably: A Longitudinal Study of Corporate Sustainable Development. Strateg. Manag. J. 2005, 26, 197-218. [CrossRef]

36. Chow, W.S.; Chen, Y. Corporate Sustainable Development: Testing a New Scale based on the Mainland Chinese Context. J. Bus. Ethics 2012, 105, 519-533. [CrossRef]

37. Ameer, R.; Othman, R. Sustainability Practices and Corporate Financial Performance: A Study Based on the Top Global Corporations. J. Bus. Ethics 2012, 108, 61-79. [CrossRef]

38. Amini, M.; Bienstock, C.C. Corporate Sustainability: An Integrative Definition and Framework to Evaluate Corporate Practice and Guide Academic Research. J. Clean. Prod. 2014, 76, 12-19. [CrossRef]

39. Engert, S.; Rauter, R.; Baumgartner, R.J. Exploring the Integration of Corporate Sustainability into Strategic Management: A Literature Review. J. Clean. Prod. 2016, 112, 2833-2850. [CrossRef]

40. Montiel, I.; Gallo, P.J.; Antolin-Lopez, R. What on Earth Should Managers Learn About Corporate Sustainability? A Threshold Concept Approach. J. Bus. Ethics 2019, 1-24. [CrossRef]

41. Xie, J.; Nozawa, W.; Yagi, M.; Fujii, H.; Managi, S. Do Environmental, Social, and Governance Activities Improve Corporate Financial Performance? Bus. Strategy Environ. 2019, 28, 286-300. [CrossRef]

42. Taliento, M.; Favino, C.; Netti, A. Impact of Environmental, Social, and Governance Information on Economic Performance: Evidence of a Corporate 'Sustainability Advantage' from Europe. Sustainability 2019, 11, 1738. [CrossRef]

43. Dorfleitner, G.; Halbritter, G.; Nguyen, M. Measuring the Level and Risk of Corporate Responsibility-An Empirical Comparison of Different ESG Rating Approaches. J. Asset Manag. 2015, 16, 450-466. [CrossRef]

44. Baregheh, A.; Rowley, J.; Sambrook, S. Towards a Multidisciplinary Definition of Innovation. Manag. Decis. 2009. [CrossRef]

45. Teubal, M.; Steinmueller, E. Government Policy, Innovation and Economic Growth: Lessons from a Study of Satellite Communications. Res. Policy 1982, 11, 271-287. [CrossRef]

46. Wu, J. Technological Collaboration in Product Innovation: The Role of Market Competition and Sectoral Technological Intensity. Res. Policy 2012, 41, 489-496. [CrossRef]

47. Molina-Morales, F.X.; Martínez-Fernández, M.T. Social Networks: Effects of Social Capital on Firm Innovation. J. Small Bus. Manag. 2010, 48, 258-279. [CrossRef]

48. Phelps, C.C. A Longitudinal Study of the Influence of Alliance Network Structure and Composition on Firm Exploratory Innovation. Acad. Manag. J. 2010, 53, 890-913. [CrossRef]

49. Guan, J.; Liu, N. Exploitative and Exploratory Innovations in Knowledge Network and Collaboration Network: A Patent Analysis in the Technological Field of Nano-Energy. Res. Policy 2016, 45, 97-112. [CrossRef]

50. Kogut, B.; Zander, U. Knowledge of the Firm, Combinative Capabilities, and the Replication of Technology. Organ. Sci. 1992, 3, 383-397. [CrossRef]

51. Xie, X.; Zou, H.; Qi, G. Knowledge Absorptive Capacity and Innovation Performance in High-tech Companies: A multi-mediating analysis. J. Bus. Res. 2018, 88, 289-297. [CrossRef]

52. Roper, S.; Love, J.H.; Bonner, K. Firms' Knowledge Search and Local knowledge Externalities in Innovation Performance. Res. Policy 2017, 46, 43-56. [CrossRef]

53. Hogan, S.J.; Coote, L.V. Organizational Culture, Innovation, and Performance: A Test of Schein's Model. J. Bus. Res. 2014, 67, 1609-1621. [CrossRef]

54. Protogerou, A.; Caloghirou, Y.; Vonortas, N.S. Determinants of Young Firms' Innovative Performance: Empirical Evidence from Europe. Res. Policy 2017, 46, 1312-1326. [CrossRef]

55. Markovic, S.; Bagherzadeh, M. How Does Breadth of External Stakeholder Co-creation Influence Innovation Performance? Analyzing the Mediating Roles of Knowledge Sharing and Product Innovation. J. Bus. Res. 2018, 88, 173-186. [CrossRef] 
56. Flammer, C.; Kacperczyk, A. Corporate Social Responsibility as a Defense against Knowledge Spillovers: Evidence from the Inevitable Disclosure Doctrine. Strateg. Manag. J. 2019, 40, 1243-1267. [CrossRef]

57. Huang, C.-J. Corporate Governance, corporate Social Responsibility and Corporate Performance. J. Manag. Organ. 2010, 16, 641-655. [CrossRef]

58. Qian, C.; Wang, H.; Geng, X.; Yu, Y. Rent Appropriation of Knowledge-based Assets and Firm Performance when Institutions are Weak: A study of Chinese Publicly Listed firms. Strateg. Manag. J. 2017, 38, 892-911. [CrossRef]

59. Berrone, P.; Gomez-Mejia, L.R. Environmental Performance and Executive Compensation: An Integrated Agency-institutional Perspective. Acad. Manag. J. 2009, 52, 103-126. [CrossRef]

60. Li, J.; He, H.; Liu, H.; Su, C. Consumer Responses to Corporate Environmental Actions in China: An Environmental Legitimacy Perspective. J. Bus. Ethics 2017, 143, 589-602. [CrossRef]

61. DiMaggio, P.J.; Powell, W.W. The Iron Cage Revisited: Institutional Isomorphism and Collective Rationality in Organizational Fields. Am. Sociol. Rev. 1983, 48, 147-160. [CrossRef]

62. Holmes, S.; Smart, P. Exploring Open Innovation Practice in Firm-nonprofit Engagements: A Corporate Social Responsibility Perspective. REd Manag. 2009, 39, 394-409.

63. Aramburu, I.A.; Pescador, I.G. The Effects of Corporate Social Responsibility on Customer Loyalty: The Mediating Effect of Reputation in Cooperative Banks Versus Commercial Banks in the Basque Country. J. Bus. Ethics 2019, 154, 701-719. [CrossRef]

64. Valentine, S.; Fleischman, G. Ethics Programs, Perceived Corporate Social Responsibility and Job Satisfaction. J. Bus. Ethics 2008, 77, 159-172. [CrossRef]

65. Arya, B.; Zhang, G. Institutional Reforms and Investor Reactions to CSR Announcements: Evidence from an Emerging Economy. J. Manag. Stud. 2009, 46, 1089-1112. [CrossRef]

66. Husted, B.W.; de Sousa-Filho, J.M. Board Structure and Environmental, Social, and Governance Disclosure in Latin America. J. Bus. Res. 2019, 102, 220-227. [CrossRef]

67. He, J.; Wang, H.C. Innovative knowledge Assets and Economic Performance: The Asymmetric Roles of Incentives and Monitoring. Acad. Manag. J. 2009, 52, 919-938. [CrossRef]

68. Surroca, J.; Tribó, J.A.; Waddock, S. Corporate Responsibility and Financial Performance: The Role of Intangible Resources. Strateg. Manag. J. 2010, 31, 463-490. [CrossRef]

69. Friedrich, R.J. In Defense of Multiplicative Terms in Multiple Regression Equations. Am. J. Political Sci. 1982, 26, 797-833. [CrossRef]

70. Aiken, L.S.; West, S.G.; Reno, R.R. Multiple Regression: Testing and Interpreting Interactions; Sage: Newcastle, UK, 1991.

(C) 2020 by the authors. Licensee MDPI, Basel, Switzerland. This article is an open access article distributed under the terms and conditions of the Creative Commons Attribution (CC BY) license (http://creativecommons.org/licenses/by/4.0/). 